\title{
Root growth of four transplant Aman rice varieties as influenced by NPKS fertilizer
}

\author{
N.C. Pal, M.A.R. Sarkar, M.Z. Hossain ${ }^{1}$ and S.C. Barman \\ Department of Agronomy, Bangladesh Agricultural University, Mymensingh-2202 \\ ${ }^{1}$ DAE, Khamarbai, Farmgate, Dhaka, Bangladesh
}

\begin{abstract}
An experiment was carried out at the Agronomy Field Laboratory, Bangladesh Agricultural University, Mymensingh, during July to December 2006 to study the root growth of four Transplant Aman rice varieties as influenced by NPKS fertilization. The experiment was laid out in a split-plot design with three replications. The experiment consisted of four varieties viz. BRRI dhan30, BRRI dhan31, BRRI dhan40 and BRRI dhan41; and four levels of fertilizers viz. 0, 50\%, 100\% and 150\% of the recommended dose of NPKS. BRRI dhan41 had better performance in all root parameters. All root parameters except number of roots hill $^{-1}$ performed better at high level of fertilizer. The interaction effect between variety and fertilizer level was significant in respect of number of roots hill $^{-1}$, fresh weight of root (except at 30 days after transplanting (DAT) and 90 DAT), dry weight of root, fresh weight of above ground plant part (except at 30 DAT and 90 DAT) and dry weight of above ground plant part (except at 90 DAT).
\end{abstract}

Keywords: Root growth, Rice varieties, NPKS fertilizer

\section{Introduction}

Research works regarding the root system of rice are very limited especially in Bangladesh. Root is the main organ of the plant through which it makes contact with the soil for anchorage and absorbing nutrient and water. The amount and rate of nutrient uptake by the plant depend on the ability of the roots to absorb nutrient and water from the soil. So, the importance of root system in the life of a plant can not be ignored. It has been pointed out that the fine branching of lateral roots and the frame work of nodal roots, including size and form of the root system, play an important role in enlarging the root surface and performing the function of a root system as a whole, but in different ways and especially their significance differs in functions such as water (Miller, 1986). Won et al. (1998) carried out experiments to develop a useful method for selection of promising cultivars for direct sowing cultivation based on analysis of root system development. In Bangladesh, research on root is still in the initial stage. In order to improve cultural practices and introduce root characters into the breeding program of crop plants, it is important to determine which of the morphological characters of the root system are modified under certain soil environments. The development of root system of the crop plant under field conditions is frequently accompanied by compensatory growth among root numbers, which is attributed to uneven soil environments. Therefore, the present study was undertaken in order to obtain accurate information on the root system morphology quantitatively and qualitatively.

\section{Materials and Methods}

The experiment was conducted at the Agronomy Field Laboratory, Bangladesh Agricultural University, Mymensingh, during the period from July to December 2006. The experimental area was characterized by Non-calcareous Dark Grey Floodplain soil belonging to the Sonatola soil series under the Old Brahmaputra Floodplain (UNDP and FAO, 1988). Soil of the experimental field was more or less neutral in reaction, low in organic matter content and its general fertility level was low. The experimental treatment comprises four Transplant 
Aman rice varieties viz. BRRI dhan30, BRRI dhan31, BRRI dhan40 and BRRI dhan41; and four levels of fertilizer- $0,50 \%, 100 \%$ and $150 \%$ of the recommended dose of NPKS. The experiment was laid out in a split plot design with three replications. The unit plot size was 4.0 $\mathrm{m} \times 2.5 \mathrm{~m}$. The nutrients $\mathrm{P}, \mathrm{K}, \mathrm{S}$ and $\mathrm{Zn}$ were applied during final land preparation in the form of triple super phosphate, muriate of potash, gypsum and zinc sulphate, respectively. The recommended dose of fertilizers were $50,60,35$ and $5 \mathrm{~kg} \mathrm{ha}^{-1}$ of urea, triple super phosphate, muriate of potash, gypsum and zinc sulphate, respectively. The recommended dose of urea fertilizer was $220 \mathrm{~kg} \mathrm{ha}^{-1}$. Urea was top dressed in three equal splits at 15, 30 and 45 days after transplanting. Healthy dry seeds of all the varieties were directly sown on 5 July 2006 in the previously prepared nursery bed. Thirty-day old seedlings were transplanted on 5 August $2006 @$ three seedlings hill ${ }^{-1}$ maintaining a spacing of $25 \mathrm{~cm} \times 15 \mathrm{~cm}$. Intercultural operations were done as and when necessary. For measurement of number of roots hill ${ }^{-1}$, root length, dry weight of root and dry weight of above ground plant part, destructive sampling of five randomly selected hills was used. Soil core samplers were used to collect the root samples. Data were analyzed statistically and the mean differences were adjudged by Duncan's Multiple Range Test (Gomez and Gomez, 1984).

\section{Results and Discussion}

\section{Effect of variety}

Number of roots hill ${ }^{-1}$, root length, root dry weight and above ground plant weight were significantly influenced by variety at 30,60 and 90 days after transplanting (DAT). BRRI dhan41 recorded the highest number of roots hill ${ }^{-1}$, the longest roots and the maximum dry weight of root and above ground plant parts at 30,60 and 90 DAT, while the minimum values were obtained with the variety BRRI dhan30 (Table 1). Similar findings are also reported by Dong et al. (2003) and Cruscial et al. (2005).

Table 1. Effect of variety on root characters of transplant Aman rice at different days after transplanting

\begin{tabular}{|c|c|c|c|c|c|c|c|c|c|c|c|c|}
\hline \multirow{2}{*}{ Variety } & \multicolumn{3}{|c|}{ No. of roots hill-1 } & \multicolumn{3}{|c|}{ Root length (cm) } & \multicolumn{3}{|c|}{ Dry weight of root (g) } & \multicolumn{3}{|c|}{$\begin{array}{c}\text { Dry weight of above ground } \\
\text { plant part }(\mathrm{g})\end{array}$} \\
\hline & 30 DAT & 60 DAT & 90 DAT & 30 DAT & 60 DAT & $90 \mathrm{DAT}$ & 30 DAT & 60 DAT & 90 DAT & 30 DAT & $60 \mathrm{DAT}$ & $90 \mathrm{DAT}$ \\
\hline$V_{1}$ & $108.83^{d}$ & $161.75^{d}$ & $179.42^{\mathrm{d}}$ & $16.98^{c}$ & $27.62^{\mathrm{d}}$ & $32.09 \mathrm{~d}$ & $1.15^{c}$ & $2.74^{\mathrm{d}}$ & $3.84^{d}$ & $3.12^{\mathrm{d}}$ & $8.31^{\mathrm{d}}$ & $19.75^{c}$ \\
\hline$V_{2}$ & $116.00^{c}$ & $170.92^{c}$ & $188.17^{c}$ & $17.92^{\mathrm{bc}}$ & $32.47^{c}$ & $35.27^{c}$ & $1.23^{c}$ & $3.18^{c}$ & $4.26^{c}$ & $3.54^{c}$ & $8.76^{c}$ & $22.13^{b}$ \\
\hline$V_{3}$ & $118.33^{b}$ & $174.75^{b}$ & $192.25^{b}$ & $18.15^{b}$ & $34.50^{\mathrm{b}}$ & $38.03^{b}$ & $1.46^{b}$ & $3.42^{b}$ & $4.5^{b}$ & $3.85^{b}$ & $9.11^{b}$ & $23.02^{b}$ \\
\hline $\mathrm{V}_{4}$ & $125.58^{a}$ & $179.92^{\mathrm{a}}$ & $198.00 \mathrm{a}$ & $20.57^{a}$ & $37.97^{a}$ & $41.19 \mathrm{a}$ & $1.77^{a}$ & $3.95^{\mathrm{a}}$ & $5.15^{\mathrm{a}}$ & $5.31^{a}$ & $10.68^{a}$ & $24.84^{a}$ \\
\hline$s \bar{X}$ & 0.52 & 0.56 & 0.88 & 0.34 & 0.45 & 0.46 & 0.04 & 0.02 & 0.04 & 0.06 & 0.12 & 0.35 \\
\hline $\begin{array}{c}\text { Level of } \\
\text { significance }\end{array}$ & ** & ** & ** & ** & ** & ** & ** & ** & ** & ** & ** & ** \\
\hline
\end{tabular}

In a column, figures with same letter or without letter do not differ significantly whereas figures with dissimilar letter differ significantly (as per DMRT).

$\mathrm{V}_{1}=$ BRRI dhan30 $\quad \mathrm{V}_{3}=$ BRRI dhan40

$\mathrm{V}_{2}=\mathrm{BRRI}$ dhan31 $\quad \mathrm{V}_{4}=$ BRRI dhan41

$\star *=$ Significant at $1 \%$ level of probability, DAT = Days after transplanting

\section{Effect of fertilizer dose}

Number of roots hill ${ }^{-1}$ was significantly influenced by different doses of fertilizer at 30,60 and 90 DAT (Table 2). The control treatment recorded the highest number of roots hill ${ }^{-1}$ and the number decreased with the increase of fertilizer level in all the cases. The longest roots at 30 , 
60 and 90 DAT were observed at high level of fertilizer doses while the shortest root length was found in the control treatment. High level of fertilizers produced the highest dry weight of root $(2.02 \mathrm{~g})$ and above ground plant parts at 30, 60 and 90 DAT and the lowest values were found in the control treatment. Similar findings are available elsewhere (Yang et al., 2004; Yamazaki and Harada, 1982).

Table 2. Effect of fertilizer on root characters of transplant Aman rice at different days after transplanting

\begin{tabular}{|c|c|c|c|c|c|c|c|c|c|c|c|c|}
\hline \multirow{2}{*}{$\begin{array}{l}\text { Fertilizer } \\
\text { dose }\end{array}$} & \multicolumn{3}{|c|}{ No. of roots hill-1 } & \multicolumn{3}{|c|}{ Root length $(\mathrm{cm})$} & \multicolumn{3}{|c|}{ Dry weight of root $(\mathrm{g})$} & \multicolumn{3}{|c|}{$\begin{array}{c}\text { Dry weight of above ground } \\
\text { plant part }(\mathrm{g})\end{array}$} \\
\hline & $30 \mathrm{DAT}$ & 60 DAT & 90 DAT & 30 DAT & 60 DAT & 90 DAT & 30 DAT & 60 DAT & 90 DAT & 30 DAT & 60 DAT & $90 \mathrm{DAT}$ \\
\hline $\mathrm{F}_{1}$ & $130.33^{a}$ & $184.50^{a}$ & $200.83^{a}$ & $15.44^{b}$ & $29.11^{c}$ & $32.52^{c}$ & $0.78^{c}$ & $2.42^{d}$ & $3.50^{\mathrm{d}}$ & $2.48^{c}$ & $7.65^{c}$ & $14.98^{c}$ \\
\hline $\mathrm{F}_{2}$ & $124.83^{b}$ & $180.83^{a}$ & $198.75^{a}$ & $17.12^{\mathrm{b}}$ & $30.91^{\mathrm{bc}}$ & $34.49 c$ & $0.95^{c}$ & $2.97^{c}$ & $4.06^{c}$ & $3.52^{\mathrm{b}}$ & $8.75^{b}$ & $19.18^{b}$ \\
\hline $\mathrm{F}_{3}$ & $111.25^{c}$ & $162.75^{b}$ & $181.25^{b}$ & $19.63^{a}$ & $34.65^{\mathrm{ab}}$ & $38.27^{b}$ & $1.84^{b}$ & $3.54 \mathrm{~b}$ & $4.68^{b}$ & $4.81^{\mathrm{a}}$ & $10.02^{\mathrm{a}}$ & $26.78^{a}$ \\
\hline $\mathrm{F}_{4}$ & $102.33^{d}$ & $159.25^{b}$ & $177.00^{\circ}$ & $21.44^{a}$ & $37.89^{a}$ & $41.29^{a}$ & $2.02^{\mathrm{a}}$ & $4.37^{a}$ & $5.53^{\mathrm{a}}$ & $5.01^{a}$ & $10.45^{\mathrm{a}}$ & $28.80^{a}$ \\
\hline$s \bar{X}$ & 0.77 & 0.86 & 0.57 & 0.51 & 0.83 & 0.5 & 0.04 & 0.02 & 0.03 & 0.05 & 0.12 & 0.46 \\
\hline $\begin{array}{l}\text { Level of } \\
\text { significance }\end{array}$ & ** & ** & ** & ** & ** & ** & ** & ** & ** & ** & ** & ** \\
\hline
\end{tabular}

In a column, figures with same letter or without letter do not differ significantly whereas figures with dissimilar letter differ significantly (as per DMRT).

$\mathrm{F}_{1}=$ No fertilizer applied (control)

$F_{2}=$ Low level of fertilizer ( $50 \%$ of the recommended dose of NPKS)

$\mathrm{F}_{3}=$ Recommended level of fertilizer (100\% of the recommended dose of NPKS)

$\mathrm{F}_{4}=$ High level of fertilizer (150\% of the recommended dose of NPKS)

** $=$ Significant at $1 \%$ level of probability, DAT = Days after transplanting

\section{Effect of interaction between variety and fertilizer dose}

Number of roots hill ${ }^{-1}$ was significantly influenced by the interaction between variety and fertilizer dose at 30 and 60 DAT, but it was not significant at 90 DAT (Table 3). At 30 DAT, the highest number of roots hill ${ }^{-1}$ (136.67) was found in the treatment combination of BRRI dhan41 and control treatment. The lowest number of roots hill ${ }^{-1}$ (94.33) was found in the treatment combination of BRRI dhan30 and high level of fertilizer dose. At 60 DAT, the highest number of roots hill $^{-1}$ (191.67) was found in the treatment combination of BRRI dhan41 and control treatment and the lowest number of roots hill $^{-1}$ (146.33) was found in the treatment combination of BRRI dhan30 and high level of fertilizer dose. Root length was not significantly influenced by the interaction between variety and fertilizer dose at 30,60 and 90 DAT (Table 3). Dry weight of root was significantly influenced by the interaction between variety and fertilizer dose at 30,60 and 90 DAT. The highest dry weight of roots was found at 30 DAT $(2.54 \mathrm{~g})$, at 60 DAT $(4.85 \mathrm{~g})$ and at 90 DAT (6.24 g), in the treatment combination of BRRI dhan41 and high level of fertilizer dose. The lowest dry weight of root was found at 30 DAT $(0.65 \mathrm{~g})$, at 60 DAT $(1.87 \mathrm{~g})$ and at 90 DAT $(2.95 \mathrm{~g})$ in the treatment combination of BRRI dhan30 and control treatment (Table 3). Dry weight of above ground plant part was significantly influenced by the interaction between variety and fertilizer dose at 30 and 60 DAT, but it was not significant at 90 DAT. The highest dry weight of above ground plant part was found at 30 DAT $(6.85 \mathrm{~g})$, at 60 DAT $(12.65 \mathrm{~g})$, in the treatment combination of BRRI dhan41 and high level of fertilizer dose. The lowest dry weight of above ground plant part was found at 30 DAT $(2.05 \mathrm{~g})$ and at 60 DAT $(7.30 \mathrm{~g})$, in the treatment combination of BRRI dhan30 and control treatment (Table 3). 
Table 3. Interaction of variety and fertilizer level on root characters of transplant Aman rice at different days after transplanting

\begin{tabular}{|c|c|c|c|c|c|c|c|c|c|c|c|c|}
\hline \multirow{2}{*}{$\begin{array}{l}\text { Variety } x \\
\text { Fertilizer } \\
\text { dose }\end{array}$} & \multicolumn{3}{|c|}{ No. of roots hill-1 } & \multicolumn{3}{|c|}{ Root length (cm) } & \multicolumn{3}{|c|}{ Dry weight of root $(\mathrm{g})$} & \multicolumn{3}{|c|}{$\begin{array}{l}\text { Dry weight of above ground } \\
\text { plant part }(\mathrm{g})\end{array}$} \\
\hline & 30 DAT & 60 DAT & 90 DAT & 30 DAT & 60 DAT & 90 DAT & 30 DAT & 60 DAT & 90 DAT & 30 DAT & 60 DAT & 90 DAT \\
\hline $\mathrm{V}_{1} \times \mathrm{F}_{1}$ & $122.33^{\text {de }}$ & $173.67^{d}$ & 190.00 & 15.03 & 23.79 & 28.10 & 0.659 & $1.87 \mathrm{i}$ & $2.95^{\mathrm{i}}$ & $2.05^{\dagger}$ & 7.30 & 12.47 \\
\hline $\mathrm{V}_{1} \times \mathrm{F}_{2}$ & $116.33^{\dagger}$ & $172.67^{\mathrm{d}}$ & 190.00 & 15.20 & 25.30 & 29.49 & $0.75^{\text {fg }}$ & $2.27^{i}$ & $3.37^{\mathrm{h}}$ & $2.78^{d}$ & $8.09 \mathrm{~g}-\mathrm{i}$ & 17.68 \\
\hline $\mathrm{V}_{1} \times \mathrm{F}_{3}$ & $102.33 i$ & $154.33^{f}$ & 172.67 & 18.10 & 29.73 & 34.33 & $1.55^{d}$ & 2.919 & $4.06 e^{e}$ & $3.75^{c}$ & $8.76^{e-g}$ & 23.64 \\
\hline $\mathrm{V}_{1} \times \mathrm{F}_{4}$ & $94.33^{k}$ & $146.33 \mathrm{~g}$ & 165.00 & 19.60 & 31.64 & 36.43 & $1.63^{d}$ & $3.91^{c}$ & $4.99 c$ & $3.90^{c}$ & $9.10^{c-e}$ & 25.19 \\
\hline $\mathrm{V}_{2} \times \mathrm{F}_{1}$ & $129.00 c$ & $184.33^{c}$ & 200.67 & 14.13 & 29.10 & 31.78 & $0.72^{\text {tg }}$ & $2.36 i$ & $3.44 \mathrm{gh}$ & $2.32^{\mathrm{ef}}$ & $7.40 \mathrm{ij}$ & 14.97 \\
\hline $\mathrm{V}_{2} \times \mathrm{F}_{2}$ & $124.33^{d}$ & $182.33^{c}$ & 199.67 & 17.43 & 31.40 & 34.26 & $0.81^{\mathrm{tg}}$ & $2.65^{h}$ & $3.72^{f}$ & $2.92^{\mathrm{d}}$ & $8.22^{\mathrm{f}-\mathrm{h}}$ & 18.07 \\
\hline $\mathrm{V}_{2} \times \mathrm{F}_{3}$ & $112.67 \mathrm{~g}$ & $161.33^{\mathrm{e}}$ & 179.33 & 19.10 & 32.63 & 35.74 & $1.60^{\mathrm{d}}$ & $3.36^{\mathrm{e}}$ & $4.44^{d}$ & $4.30^{\mathrm{b}}$ & $9.65^{b c}$ & 27.09 \\
\hline $\mathrm{V}_{2} \times \mathrm{F}_{4}$ & 98.00 & $155.67^{\dagger}$ & 173.00 & 21.03 & 36.77 & 39.29 & $1.77^{\mathrm{cd}}$ & $4.36^{b}$ & $5.44^{b}$ & $4.60^{\mathrm{b}}$ & $9.78^{\mathrm{bc}}$ & 28.37 \\
\hline $\mathrm{V}_{3} \times \mathrm{F}_{1}$ & $133.33^{b}$ & $188.33^{b}$ & 203.67 & 14.63 & 30.43 & 33.46 & $0.83^{\text {tg }}$ & $2.62^{\mathrm{h}}$ & $3.69^{\mathrm{fg}}$ & $2.57^{\mathrm{de}}$ & $7.73^{h-j}$ & 15.95 \\
\hline $\mathrm{V}_{3} \times \mathrm{F}_{2}$ & $128.67^{c}$ & $183.33^{c}$ & 201.33 & 16.50 & 32.33 & 35.65 & $0.92^{f}$ & $3.07^{\dagger}$ & $4.17 \mathrm{e}$ & $3.70^{c}$ & $8.88^{\mathrm{d}-\mathrm{f}}$ & 19.62 \\
\hline $\mathrm{V}_{3} \times \mathrm{F}_{3}$ & $109.00^{\mathrm{h}}$ & $164.00^{\mathrm{e}}$ & 182.33 & 19.84 & 36.20 & 39.98 & $1.93^{c}$ & $3.66^{d}$ & $4.72^{c}$ & $4.43^{b}$ & $9.59^{b-d}$ & 26.58 \\
\hline$V_{3} \times F_{4}$ & $102.33^{i}$ & $163.33^{\mathrm{e}}$ & 181.67 & 21.62 & 39.04 & 43.04 & $2.15^{b}$ & $4.36^{b}$ & $5.43^{b}$ & $4.70^{\mathrm{b}}$ & $10.26^{b}$ & 29.92 \\
\hline $\mathrm{V}_{4} \times \mathrm{F}_{1}$ & $136.67^{\mathrm{a}}$ & $191.67^{\mathrm{a}}$ & 209.00 & 17.97 & 33.10 & 36.75 & $0.93^{f}$ & $2.84 \mathrm{~g}$ & $3.91^{\mathrm{ef}}$ & $2.97^{d}$ & $8.17^{\text {th }}$ & 16.52 \\
\hline $\mathrm{V}_{4} \times \mathrm{F}_{2}$ & $130.00^{c}$ & $185.00^{\mathrm{c}}$ & 204.00 & 19.33 & 34.61 & 38.57 & $1.33^{e}$ & $3.88^{c}$ & $4.98^{c}$ & $4.67^{b}$ & $9.82^{\mathrm{bc}}$ & 21.34 \\
\hline $\mathrm{V}_{4} \times \mathrm{F}_{3}$ & $121.00^{\mathrm{e}}$ & $171.33^{\mathrm{d}}$ & 190.67 & 21.47 & 40.02 & 43.03 & $2.27^{b}$ & $4.22^{b}$ & $5.48^{b}$ & $6.74^{\mathrm{a}}$ & $12.07^{a}$ & 29.79 \\
\hline $\mathrm{V}_{4} \times \mathrm{F}_{4}$ & $114.67^{\mathrm{fg}}$ & $171.67^{d}$ & 188.33 & 23.51 & 44.14 & 46.39 & $2.54^{\mathrm{a}}$ & $4.85^{\mathrm{a}}$ & $6.24^{a}$ & $6.85^{a}$ & $12.65^{\mathrm{a}}$ & 31.72 \\
\hline${ }_{s} \bar{X}$ & 1.04 & 1.13 & 1.77 & 0.68 & 0.90 & 0.91 & 0.07 & 0.05 & 0.09 & 0.13 & 0.24 & 0.71 \\
\hline $\begin{array}{l}\text { Level of } \\
\text { significance }\end{array}$ & ** & ** & NS & NS & NS & NS & ** & ** & ** & 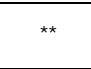 & ** & NS \\
\hline
\end{tabular}

In a column, figures with same letter or without letter do not differ significantly whereas figures with dissimilar letter differ significantly (as per DMRT)

DAT = Days after transplanting

$\mathrm{V}_{1}=$ BRRI dhan30 $\quad \mathrm{F}_{1}=$ No fertilizer applied (control)

$V_{2}=$ BRRI dhan31 $\quad F_{2}=$ Low level of fertilizer (50\% of the recommended dose of NPKS)

$\mathrm{V}_{3}=\mathrm{BRRI}$ dhan $40 \quad \mathrm{~F}_{3}=$ Recommended level of fertilizer (100\% of the recommended dose of NPKS)

$\mathrm{V}_{4}=\mathrm{BRRI}$ dhan41 $\quad \mathrm{F}_{4}=$ High level of fertilizer (150\% of the recommended dose of NPKS)

** $=$ Significant at $1 \%$ level of probability

NS = Not significant.

\section{References}

Crusciol, C.A.C., Mauad, M, Alvarez, R.de.C.F., Lima, E.do.V. and Tiritan, C.S. 2005. Phosphorus doses and root growth of upland rice. Bragantia. 64(4): 643-649.

Dong, G.C., Wang, Y.L., Wu, H., Wang, J.G., Cai, H.R. and Cai, J.Z. 2003. Effect of nitrogen on root morphometrics at different stages in rice. J. Shanghai Jiaotong Univ. Agril. Sci. 21(4): 331-334.

Gomez, K.A. and Gomez, A.A. 1984. Statistical Procedure for Agricultural Research. Intl. Rice Res. Inst., John Willey and Sons, New York, Chichester, Brisbane, Toronto, Singapore. pp. 1-340.

Miller, D.E. 1986. Root systems in relation to stress tolerance. Horticultural Sciences. 21: 963-970.

UNDP and FAO. 1988. Land Resources Appraisal of Bangladesh for Agricultural Development. Report 2. Agroecological Regions of Bangladesh. Bangladesh Agril. Res. Coun., Dhaka-1207. pp. 212-221.

Won, J.G., Hirahara, Y., Yoshida, T. and Won, J.G. 1998. Selection of cultivars for direct seeding in rice based on the development of root system analysis. J. Faculty Agric., Kyushu Univ. 43(1-2): 31-37.

Yamazaki, K. and Harada, J. 1982. The root system formation and its possible bearings on grain yield in rice plants. Japan Agril. Res. Quarterly. 15(3): 153-160.

Yang, C.M., Yang, L.Z., Yang, Y.X. and Ouvang, Z. 2004. Rice root growth and nutrient uptake as influenced by organic manure in continuously and alternately flooded paddy soils. Agril. Water Management. 70(1): 67-81. 